\title{
Managerial Responsibilities on the Micro Level
}

\author{
LaRue Tone Hosmer
}

I $t$ is possible to think of the responsibilities of corporate managers on either the macro level-accountable to whom-or the micro level-accountable for what. Discussions of managerial responsibilities on the macro "to whom" level have been ongoing for years, certainly since Berle and Means (1936) first noted the replacement of company owners by professional managers, without reaching a widely accepted conclusion. Perhaps instead of continuing those discussions it would be well to move back a step, or down a notch, and begin to consider the micro, "for what" responsibilities of management. What activities should corporate managers be held accountable to perform, and to perform well?

Before starting to discuss the activities we can reasonably expect the managers of business firms to perform, and perform well, let me make a few comments about the problem of reaching a widely shared conclusion on the responsibilities of management at the macro level. It is a basic tenet of commercial law that managers are accountable primarily to the owners of the business. It is a basic principle of neoclassical economics that managers are accountable solely to the stockholders of the firm. People who adopt the very logical thought structures-the "ways of looking at the world"-_of either the legal system or the market paradigm are not easily going to give up one of their most crucial underlying assumptions. We may disagree-and by "we" I mean the normative ethicists and social philosophers who are contributing articles to this special edition of Business Horizons - but that does not mean that we will be able to convince attorneys or economists. Most of us in this issue believe that the macro responsibilities of corporate managers have to be extended to the society of which the company is a part, rather than be limited to a small segment of owners within that society. Most of us think that a substantial num- ber of compelling arguments have been presented in support of that view (Stone 1975, Velasquez 1982 , DeGeorge 1982, Hosmer 1984, McCoy 1985, Bowie 1991). Most of us recognize, however, that we have not convinced advocates of the rule of law or of the power of markets; had we done so this special edition would not be needed.

My suggestion, given that lack of success, is that we should move from the "to whom" issue on to the "for what" question. This article is a first step in that direction. Others may have tried this approach - it is certainly the basis for managerial control (Anthony, Reece, and Welsch 1985)-but I am not conscious of any earlier efforts that looked at ethical rather than financial accountability. If it is indeed a first step, then I would hope that readers will tolerate a few rough edges along the way.

I would argue that the basic activities we can legitimately expect managers to perform, and perform well, can easily be identified by examining the curriculum at a series of reputable schools of business administration, and by considering the content of a number of reputable texts on business management. I would further argue that this set of activities can be roughly divided into strata reflecting the assignment of those tasks to the different levels of management in a hierarchical structure. And I would lastly argue that the activities within each stratum can be generally associated with a set of reasonably explicit performance criteria, or responsibilities.

There is nothing very new here and, I would hope, nothing very controversial. All I am saying is that we can identify a different set of manage- 


\section{Figure 1}

\section{A Hierarchy of Managerial Responsibilities}

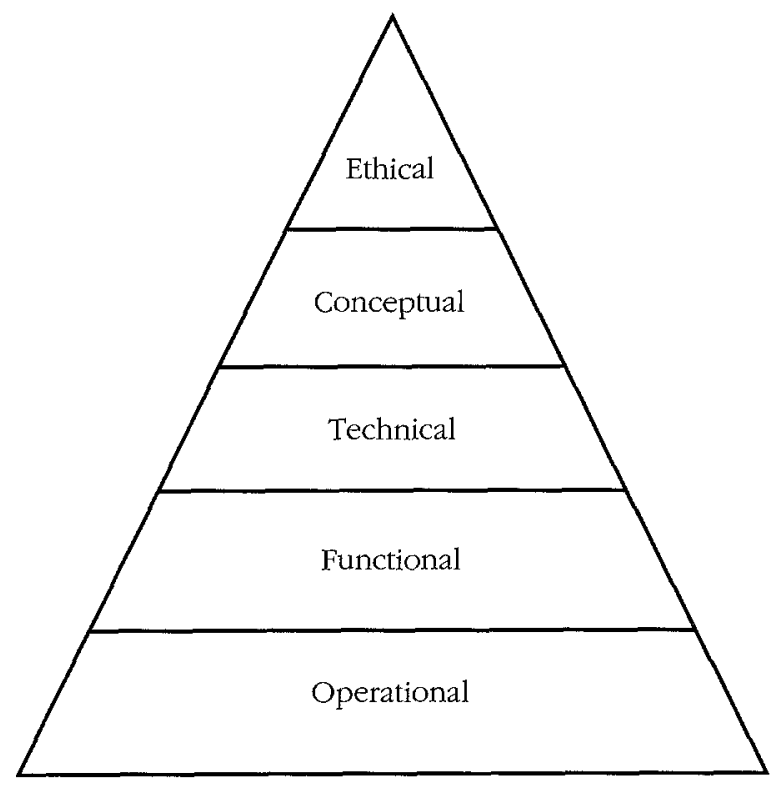

rial activities at each level within an organization, that we can set up a different set of performance criteria for each level, and that we can reasonably expect to hold managers accountable to those criteria. I have proposed five strata and 15 criteria. You might prefer four and 12 , or six and 18 The numbers are not important. The belief that we can identify, assign, and measure the performance of different managerial activities is important. I would hope that we all are willing to accept that belief for now.

I said that there was nothing very new in the concept of a hierarchy of managerial activities within a business firm, with a set of performance criteria or managerial responsibilities associated with each level within the hierarchy, and I assume that is correct. I recognize, however, that there is something new in placing a set of "ethical" activities and responsibilities at the apex of that hierarchy rather than in diffusing them throughout all levels of the organization (see Figure 1), and I understand that this placement may appear controversial to some.

My argument in support of that placement, which I should like to summarize very briefly here, is that we - and once again by "we" I mean the normative ethicists and social philosophers who are concerned that business firms and business people operate in a manner that can be described as "right" and "proper" and "just"have downplayed the importance of our field of study. We have looked upon our theories as pe- ripheral to the management of the firm rather than as central to that management, as corrections to wrongful behavior rather than as directives for tightful action.

It seems clear to me that the conditions of management have changed, and consequently that the activities of management must also have changed or be now in the process of changing. Business firms have become larger in size, more complex in form, and much more competitive in nature. My argument is that as we move from small, simple, relatively non-competitive firms to those that are large, complex, and very competitive, we also move from focusing on the lower to concentrating on the higher of these managerial activities. I think it is fairly easy to demonstrate that progression from the operational through the functional and technical levels to the conceptual (or strategic). The purpose of this article is to show that the next step in that progression will necessarily be to the ethical level.

By "ethical level," I mean the activities of management that result in a distribution of the benefits produced by the firm and an allocation of the costs imposed by the firm in a manner that can be described by the various stakeholders of the firm as "right" and "proper" and "just." This is not an activity currently performed by most business executives. This is not an activity currently taught at most business schools. My argument is that as businesses become larger, more complex, and much more competitive, they also become much more dependent--on their workers, managers, technicians, executives, suppliers, distributors, customers, creditors, owners, and the local, regional, and national voters.

My final argument is that this process of increasing dependence is not ongoing; it is complete. Large, complex and globally competitive firms have become dependent upon their stakeholders. Senior executives must, therefore, ensure the cooperation and commitment of these stakeholders. It is no longer enough to say that it would be nice, somehow, if senior executives recognized their social responsibilities to others. Now we can say it is essential that senior executives perform their managerial responsibilities in a way that will benefit their firms by increasing the cooperation and commitment of the stakeholders.

In one last paragraph of introduction, let me suggest that the same progression over time from the operational level to the functional and technical levels through to the conceptual level that can be seen in the activities at business firms, can also be seen in the courses at business schools. Schools of business administration have moved over the past 25 years from teaching the basic principles useful in operational management, to the quantitative models applicable in the func- 
tional departments, to the computer systems needed for the technical areas, to the competitive concepts required for strategic planning. In the next five years I forecast that these schools will move even further, to the ethical principles required for stakeholder commitment.

In summary, the argument of this paper is that the global conditions of management have changed, that firms now operate as extended organizations dependent upon their stakeholder groups. In this environment, senior executives have the ultimate micro "for what" responsibility to build commitment among those groups and should be held accountable for that commitment. Let me now start my support of this argument at the bottom of the proposed hierarchy of administrative activities and responsibilities, and work up.

\section{ACTIVITIES AND RESPONSIBILITIES}

A t the bottom of the administrative hierarchy is the operational level, where prodserved, revenues are generated, and bills are paid. For many smaller firms, particularly in the basic service industries, this is the primary level of activity and responsibility. In these small organizations there is little need for quantitative analysis in the functional areas of marketing, production, or finance; close contacts with customers, workers, and creditors seem more effective. There is little need for advanced systems in the technical areas of human staffing, data processing, and product/process design; manual methods and desktop computers seem quite suitable. There is even limited concern for the competitive concepts of scale/scope economies, entry barriers, and learning curves; a good shop or store location with plenty of parking seems more desirable.

Good operating level companies don't planthey do. They seem to adapt naturally to local conditions, and they usually remain successful as long as the local economies upon which they are dependent prosper. Personal time, effort, and leadership are all required, of course, but the owners and managers (often combined in one person or one family or one group) appear to look upon their primary tasks as satisfying customers, improving methods, and conserving assets. These, I would like to think, are also the most basic performance outcomes we should be able to expect from corporate managers. They are often forgotten in the largest companies, unfortunately, but some of the most famous managerial texts and articles (Ouchi 1981 or Peters and Waterman 1982) have done little more than remind corporate managers and others of these most basic operational responsibilities.
The next level of activity in most corporations is that of functional management, where planning begins to supplant doing. Marketing policies are established through analytical approaches to pricing levels, distribution channels, and promotional means. Production policies are arranged by mathematical programs for machine scheduling, line balancing, and job sequencing. Financial policies are developed through economic comparisons of investment projects, lease/ purchase arrangements, and debt/equity structures. Here we have the province of the quantitative techniques taught so extensively in schools of business administration. The expected outcomes of the application of these techniques are the maximization of revenues, minimization of costs, and optimization of returns. These, I think we can easily claim, are the performance criteria and micro-level responsibilities of management at the functional level.

The third level of activity is that of technical management, where the human and machine capabilities for improved planning and performance are developed. Human resource departments are set up to select, train, motivate, and involve employees. Data processing departments are established to record, organize, transmit, and provide access to information. Engineering departments are charged to shorten the design cycles for both products and processes by involving employees and making use of information from all of the functional departments. The expected outcomes of corporate managers at this level include the involvement of people, the utilization of information, and the design of new products and processes. Again, we can set these up as the performance criteria and micro-level responsibilities of management at the technical level.

The fourth level of activity is that of conceptual management. This is the level that was originally termed strategic planning or strategic management. In the early 1970 s strategic planning primarily focused on the direction of the firm. "If you don't know where you're going, any road will take you there" was a popular phrase repeated at many conferences and in many classrooms. This obviously true but not particularly insightful belief was expressed with much greater precision by Kenneth Andrews (1980), when he defined strategy as "the pattern of the goals and objectives of the organization and the design of the major policies and procedures to achieve those goals and objectives stated in such a way as to define the nature of the business and the character of the company." Strategy, in Andrews' model, matched the opportunities and risks in the environment (what should we do?) with the strengths and weaknesses of the firm (what can we do?) and with the values and attitudes of the 


\section{Figure 2 \\ Performance Criteria for Non-Controversial Areas}

$\begin{array}{ll}\begin{array}{l}\text { Operational } \\ \text { Management }\end{array} & \begin{array}{l}\text { Satisfying customers } \\ \text { Improving products } \\ \text { Conserving assets }\end{array} \\ \begin{array}{l}\text { Functional } \\ \text { Management }\end{array} & \begin{array}{l}\text { Maximizing revenues } \\ \text { Minimizing costs } \\ \text { Optimizing returns }\end{array} \\ \begin{array}{l}\text { Technical } \\ \text { Management }\end{array} & \begin{array}{l}\text { Involving people } \\ \text { Applilizing information } \\ \text { Conceptual }\end{array} \\ \text { Management } & \begin{array}{l}\text { Setting objectives } \\ \text { Gaining advantages } \\ \text { Building competences }\end{array} \\ & \end{array}$

management (what do we want to do?). He concluded that the range of options open to the company often was an "embarrassment of riches" that could be achieved through geographic expansion, product diversification, or vertical integration.

The embarrassment of riches faded quickly in the early 1980s with the advent of intense global competition. Strategic planning became not so much the direction of the firm to achieve corporate objectives, as the positioning of the firm to gain competitive advantages. Michael Porter (1980) described the five forces that determined the profitability of an industry (supplier power, customer power, new entrants, substitute products, and producer rivalry). It was now necessary to consider entry barriers, value chains, scale and scope economies, experience curves, competitor intentions, customer preferences, distributor restrictions, and national policies in selecting the strategy of the firm. C. K. Prahalad (1990) added the need to build an architectural framework of competitive strategies based upon a foundation of core competencies. Combining Andrews, Porter, and Prahalad results in specifying the expected outcomes of management at the conceptual level as setting achievable objectives, gaining competitive advantages, and building core competencies.

The 12 performance criteria from the four non-controversial levels of managerial activities are summarized in Figure 2. If those activities were performed well, and if the criteria were met fully, then most people would agree that the firm was operating with adequate economic efficiency (converting scarce resources into wanted goods and services at minimal costs) and with satisfactory competitive effectiveness (providing returns or achieving "rents" above the mean for all other firms within the industry).

The question now is: Is this enough? Can we realistically expect to hold corporate managers accountable for anything more than satisfying customers, improving products, and conserving assets in such a way as to achieve adequate economic efficiency and satisfactory competitive effectiveness?

The response of most normative ethicists and social philosophers is that it is not enough. They-and I-would say that business firms are not simple black boxes that transform scarce resources into needed goods and services with adequate economic efficiency, and that maintain an industry position with satisfactory competitive effectiveness. They and I would claim that business firms consist of people. These people exist both within the organization (operational employees, functional managers, technical staff, senior executives, and company owners) and outside the organization (retail and industrial customers, material and component suppliers, wholesale and retail distributors, bank and trade creditors, local residents, national citizens, and global inhabitants). These people can be harmed by company actions on such diverse issues as employee layoffs, salary differentials, plant closings, workplace dangers, pension reversions, tax rebates, political contributions, advertising claims, package sizes, pharmaceutical prices, foreign payments, owl habitats, photo exhibits, job exports, and management incentives. These people, we claim, are owed thoughtful consideration. These people, we insist, represent the macro level "to whom" responsibilities of management.

"Why?" respond those who believe in legal systems and market paradigms. "Laws will-or should-prevent anyone from lying, cheating, stealing or colluding, and markets will-or again should-adjust supply costs, salary levels, production rates, and product prices so resources are used for their highest purpose. We grant that it is distressing for an employee to be laid off, but there is a labor market out there for his or her skills. We understand it is disturbing for a forest to be cut down, but there is a factor market out there for the trees and the price in that market indicates that society values lumber for building houses more than woodland for camping trips."

Our answer, of course, is that often laws don't reflect current social values, markets don't adjust to long-term consumer preferences, and prices don't include the external costs (environmental pollution and resource depletion) associated with the products and processes. The answer of our critics to these charges is that they are not advocating obsolete laws, inefficient markets, or incomplete prices, and that together we must change the laws, improve the markets, and 
complete the prices. We in turn respond that those are impossible requirements. Ethicists and advocates of the legal system and the market paradigm have never been able to achieve agreement on the macro-level responsibilities of corporate managers to society. I doubt they ever will do so because-as explained earler, in the introduction to this paper-those macro "to whom" responsibilities contradict basic theoretical assumptions in both legal and economic thought.

\section{THE EXTENDED VIEW OF THE BUSINESS FIRM}

$\mathrm{L}$ et us return, instead, to the micro "for what" responsibilities of corporate managers, where we may be able to achieve agreement. Let us also, for now, adopt the "extended" view of a business firm. In this view, a company consists of much more than just the property it owns, the material it uses, the people it employs, and the product it produces. In this view a company also consists of a set of relationships with material and component suppliers, credit and equity institutions, worker and managerial/techanical staff sources, wholesale and retail distributors, and industrial and individual customers. In this view a company further consists of a set of dependencies upon national communication, transportation, education, and health care systems, and upon global trade agreements, monetary exchanges, factor costs and environmental constraints. This extended view of a business firm is shown graphically in Figure 3.

There is not space in this article to trace the theoretical development and list the empirical support for the extended view of business firms. Let me just state, for those who are perhaps somewhat hesitant to accept this view without further thought, that the largest supply expense for General Motors in 1990 was not for the purchase of steel or rubber or engines or tires, but for the purchase of employee health care. Let me also state that the largest current problem for many microelectronic and bioengineering firms is not the intensity of global competition, but the shortage of technical staff. Companies compete based upon their costs and skills. Corporate managers cannot ignore those costs and skills and still achieve adequate economic efficiency and satisfactory competitive effectiveness.

If you are willing, for now, to accept the extended view of a business organization, then I would hope that you would be willing to accept the collateral argument that it is the micro-level responsibility of senior executives to deal with the major costs and major problems revealed by that view. If health care is a major overhead cost, and if overhead cost is a major problem in global competition, then it is the responsibility of senior
Figure 3

An Extended View of a Business Organization

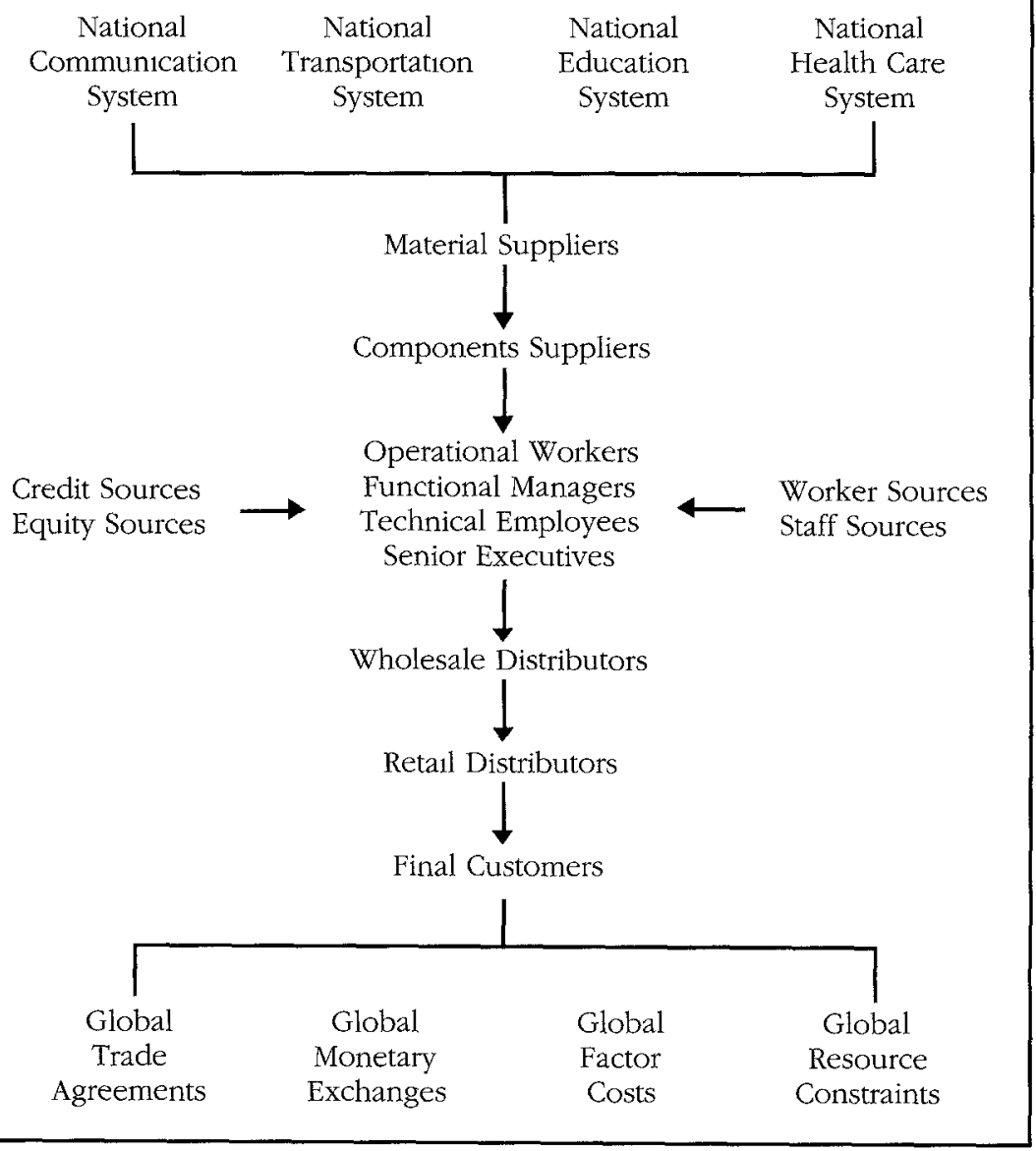

executives to attempt to control that cost. The cost of health care, however, cannot be controlled by changes in technology or advances in efficiency; at all events we can say with considerable confidence that the cost of health care has not been controlled in the past by technology or efficiency.

The problem in the cost of health care is not technology nor efficiency. The problem is that the demand has far outstripped the supply, and we no longer have the uncommitted resources on the national level to increase the supply. So controlling health care costs at the corporate level means either reducing the benefits distributed to the employees and retirees, or reducing the amounts paid to the providers. When you reduce benefits or payments you are imposing harms upon others in ways outside their own control. When you impose harms upon others in ways that are outside of their own control, my argument is that you have moved from the conceptual to the ethical level in the hierarchy of managerial activities and responsibilities. 


\section{THE ETHICAL LEVEL OF ACTIVITIES AND RESPONSIBILITIES}

$\mathrm{W}$ hat, then, are the activities and responsibilities of management at the ethical level? The activities at this level are the distribution of the benefits generated by the firm and the allocation of the costs or harms imposed by the firm. Distributing benefits, of course, is easy and pleasant work. It is always easy to raise salaries, pay bonuses, announce expansions. It is always pleasant to offer contracts, build plants, raise dividends.

Allocating harms, however, is not easy and pleasant work. It is not easy to cut salaries, eliminate bonuses, announce restructurings. It is not pleasant to cancel contracts, close plants, reduce dividends. Yet often this has to be done. We have entered a period of intense global competition when costs have to be cut, plants have to be closed, and contracts have to be canceled. This has to be done, and my argument is that it has to be done well.

Distributing benefits and allocating harms "well" does not mean just performing these activities harshly or sternly or with a lack of care and compassion. Performing these activities "well" means that the distribution of benefits and allocation of harms is accomplished in such a way that the stakeholders within the firm (operational employees, functional managers, technical staff, and senior executives), within the industry (material and component suppliers, credit and equity sources, workers and managerial/technical communities, and wholesale and retail distribu-

\section{Figure 4}

\section{Performance Criteria Including the Ethical Level}

$\begin{array}{ll}\begin{array}{l}\text { Operational } \\ \text { Management }\end{array} & \begin{array}{l}\text { Satisfying customers } \\ \text { Improving products } \\ \text { Conserving assets }\end{array} \\ \begin{array}{l}\text { Functional } \\ \text { Management }\end{array} & \begin{array}{l}\text { Maximizing revenues } \\ \text { Optimizing costs }\end{array} \\ \text { Technical } & \begin{array}{l}\text { Involving people } \\ \text { Utilizing information } \\ \text { Applying technology }\end{array} \\ \text { Conceptual } & \begin{array}{l}\text { Setting objectives } \\ \text { Gaining advantages } \\ \text { Building competences }\end{array} \\ \text { Ethical } & \begin{array}{l}\text { Gaining commitment } \\ \text { Expanding cooperation } \\ \text { Management } \\ \text { Creating community } \\ \text { Organizational Effort }\end{array}\end{array}$

tors), and within the country (local residents, regional inhabitants, and national citizens) will consider that distribution and that allocation to have been "right" and "proper" and "just."

Why is there any need to be "right" and "proper" and "just" in the distribution of benefits and the allocation of harms? If a company is dependent upon its stakeholders in an extended organization, then the managers of that company need the cooperation and even the commitment of those stakeholders to achieve economic efficiency and competitive effectiveness. I know of no direct empirical evidence to support this view, but certainly we have all had adequate personal experiences to indicate that stakeholders who believe that they have been treated "wrongly" or "improperly" or "unjustly" tend to be neither cooperative nor committed.

My argument is that the stakeholders in an extended organization who believe they have been treated "rightly" and "properly" and "justly" tend to develop a sense of community that leads to a total organizational effort. That effort is needed to achieve the desired goals of economic efficiency and competitive effectiveness. That effort is the final responsibility of management at the micro level, as shown in Figure 4.

How can senior executives convince the stakeholders of the firm that they have been treated "rightly" and "properly" and "justly"? Freeman (1984) has suggested a series of explicit negotiations with the various stakeholder groups, but that would require that each group have a formal structure and designated individuals to conduct the negotiations. Further, conducting the negotiations would be a cumbersome, time-consuming process.

My suggestion would be that senior executives make use of ethical principles rather than economic imperatives in deciding on the distribution of benefits and the allocations of harms. Is this distribution or this allocation "right"? Is it "proper"? Is it "just"? I freely admit that I am what Thomas Dunfee (1991) terms an ecumenical ethicist and search for a preponderance or convergence among a set of ten Western ethical theories rather than rely upon the outcome of a single ethical principle. I don't, however, think that the basis-single principle or multiple principles-of moral reasoning matters in this instance. What does matter is that the final decision on the distribution of benefits or the allocation of harms is "more right" and "more proper" and "more just" than if just economic factors were considered, and that it is seen as "more right" and "more proper" and "more just" by the stakeholders. hat are the responsibilities of the senior executives at the ethical level in the managerial hierarchy of the firm? 
They have the responsibility-and should be held accountable for the outcome-to improve the cooperation and to increase the commitment of all of the stakeholders of the firm. This requires the distribution of the benefits and the allocation of the harms generated by the firm in a way that is seen by the stakeholders of that firm as "right" and "proper" and "just." The micro "for what" and the macro "to whom" responsibilities of corporate managers converge at the ethical level of management.

\section{References}

K.R. Andrews, The Concept of Corporate Strategy (Homewood, Ill.: Richard D. Irwin, 1980).

R.A. Anthony, J.S. Reece, and G. Welsch, Fundamentals of Management Accounting (Homewood, Ill.: Richard D. Irwin, 1985)

A.A. Berle and G.C. Means, The Modern Corporation and Private Property (New York: Harcourt, Brace \& World, 1936).

N.E. Bowie, "Challenging the Egoistic Paradigm," Business Etbics Quarterly, 1 (1991): 1-22.

R.T. DeGeorge, Business Etbics (New York: Macmillan, 1982).

T.W. Dunfee, "Business Ethics and Extant Social Contracts," Business Ethics Quarterly, 1 (1991): 23-51.

R.E. Freeman, Strategic Management: A Stakebolder Approach (Marshfield, Mass.. Pitman, 1984).
L.T. Hosmer, "Managerial Ethics and Microeconomic Theory," Journal of Business Etbics, 4 (1984): 17-23.

C.S. McCoy, Management of Values: The Ethical Difference in Corporate Policy and Performance (Marshfield, Mass.: Pitman, 1985).

W.G. Ouchi, Theory $Z$ (Reading, Mass.: AddisonWesley, 1981).

T.J. Peters and R.H. Waterman, In Searcb of Excellence (New York Harper \& Row, 1982).

M.E. Porter, Competitive Strategy: Techniques for Analyzing Industries and Competitors (New York: Free Press, 1980).

C.K. Prahalad and G. Hamel, "The Core Competence of the Corporation," Harvard Business Revnew, MayJune 1990, pp. 79-93.

C.D. Stone, Where the Lau Ends. The Social Control of Corporate Bebavior (Boston: Harper \& Row, 1975).

M.G. Velasquez, Business Ethics: Concepts G Cases (Englewood Cliffs, N.J.: Prentice-Hall, 1982).

LaRue Tone Hosmer is a professor of corporate strategy and managerial ethics at the Graduate School of Business Administration, University of Michigan, Ann Arbor. 